\title{
Zs Research Square \\ Complement Component 3 (C3) Concentrations in Cancer Patients: A Systematic Review and Meta-Analysis
}

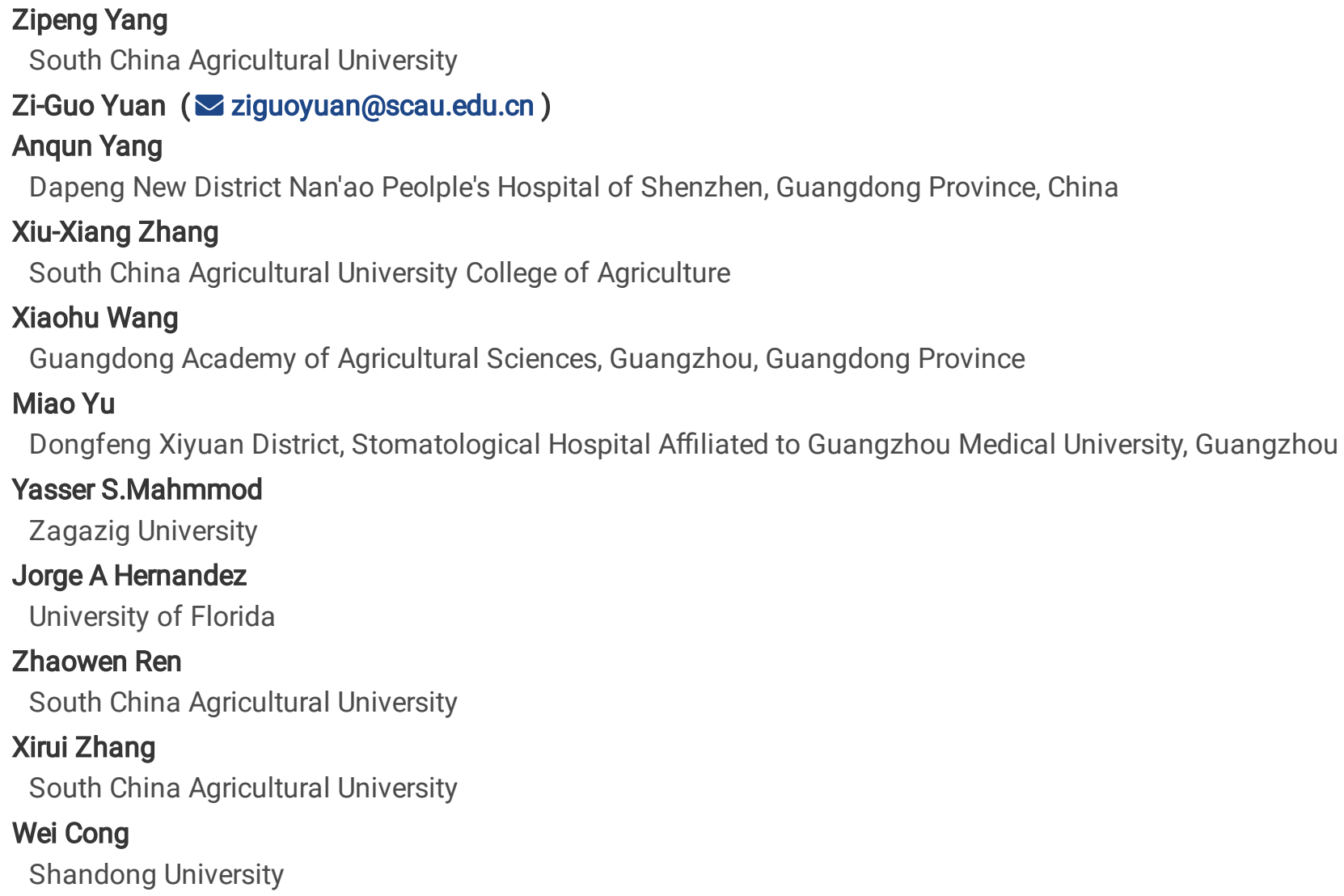

Research article

Keywords: Complement Component 3, Cancer Patients, Meta-Analysis

Posted Date: March 26th, 2020

DOI: https://doi.org/10.21203/rs.3.rs-18256/v1

License: (c) (i) This work is licensed under a Creative Commons Attribution 4.0 International License. Read Full License 


\section{Abstract}

\section{Background}

The aim of this study was to investigate the association between the serum complement component 3 "C3" level and the patients with different types of cancer. Our study finding would ultimately provide reliable scientific conclusions to guide clinical practice.

Methods

PubMed, Embase, The Chorane Library and Google Scholar were systematically searched to identify all studies on serum C3 concentrations in cancer patients published as of September 2019. Additionally, we conducted a clinical study on serum C3 in lung cancer patients and healthy people. The levels of serum complement C3 in 84 lung cancer patients and 30 healthy people were examined by ELISA. We used standardized mean differences (SMD) to report the pooled estimation, and $\mathrm{I}^{2}$ statistics were calculated to examine the heterogeneity. For pooling estimates, a fixed effect meta-analysis was conducted on our studies. Two independent reviewers extracted relevant data and conducted deviation risk assessment. Our Meta-analysis was performed using STATA software and Review Manager 5.3.

Results

The C3 levels of 83 lung cancer patients were $1.07 \pm 0.34$, and 30 healthy people were $0.95 \pm 0.17$ (the unit is $\mathrm{g} / \mathrm{l}$, keep two decimal places after the decimal point), and the $p$-value for t-test was $0.014(<0.05)$. The overall C3 concentrations of cancer patients were significantly higher than the healthy control (SMD:0.30, $95 \% \mathrm{Cl}=0.20$ to $0.40, \mathrm{p}$-value $<0.00001)$. There was a certain degree of heterogeneity in the article, but it was acceptable $\left(\chi^{2}=31.89, p\right.$-value $\left.=0.02, I^{2}=44 \%\right)$.

\section{Conclusions}

Concentration analysis and this meta-analysis revealed that the serum C3 concentrations in cancer patients are significantly higher than that of healthy people. Further well-designed, large-scale, randomized controlled trials are needed to confirm this conclusion.

Keywords : Complement Component 3; Cancer Patients; Meta-Analysis

\section{Background}

Cancer refers to malignant tumors originating from epithelial tissues, which is one of the non-communicable diseases and has become the main cause of death in the world [1]. It is estimated that there will be 18.1 million new cases and 1.6 million cancers worldwide in 2018 [1]. More worrying, however, is that the number of cancer deaths worldwide will continue to rise and is estimated to reach 11 million by 2030 [2]. Despite cancer poses a serious threat to human health, previous studies have documented that a huge number of cancer-related deaths are preventable [3]. Approximately, 30-40\% of new cancer cases and nearly $60 \%$ of cancer deaths can be avoided by prevention from verified and modifiable risk factors [4].

The complement system is part of the innate and acquired immune system. Complement is composed of more than 30 kinds of proteins and widely exist in serum, tissue fluids, and cell membrane surfaces with a precise regulation mechanism. It plays an important role in the activation of innate immune response system through three different pathways the classical, lectin, and alternative pathways[5].

Complement Component 3 (C3) is the central molecule of the complement system. All complement pathways are concentrated on the $\mathrm{C} 3$ molecule, which can be decomposed into $\mathrm{C} 3 \mathrm{a}$ and $\mathrm{C} 3 \mathrm{~b}$ by protease cleavage and it can be activated automatically on the surface of microorganisms or by other proteases such as kallikrein and thrombin molecules, which is known as alternative pathway activation[6-8]. Complement activation on tumor cells leads to the production and covalent connection of C3 activated fragments. Opsonin complement receptor, a common C3 activated fragment, is expressed by phagocytes and 
natural killer (NK) cells. It participates in complement C3 receptor tumor, which can enhance antitumor activity [9]; $[10,11]$. Complement activation also, leads to the production of C3a product, which is a decomposition product of C3 that, eventually forms a cytolytic membrane attack complex (MAC) and enhances the antitumor effect in the body [9]. However, many soluble and membrane-bound proteins play an important role in regulation of complement activity at different levels because complement may be potentially harmful to the body tissues [12]. Improper complements activation can lead to many abnormal physiological and pathological sequelae, which are the basis of many diseases, including inflammatory diseases and cancer[13].

C3 plays an important role in the occurrence, development and immune process against tumor. However, the imbalance of the complement system may play a comprehensive and systematic role in the occurrence and development of tumors [14]. Previous research has shown that different concentrations of C3a may play different roles in tumor cells, suggesting that complement C3 may be important in the development of tumors and may be concentration dependent [15].

At present, only a few clinical studies emphasize the functional importance of complement resistance to tumor cell survival and disease progression [16]. Retrospective studies of serum C3 concentration in cancer patients are under explored to a large extent and the data is controversial. Considering the importance of complement C3 in tumor pathogenesis, it is crucial to obtain clinical information on the serum C3 concentrations of cancer patients in order to provide reliable scientific conclusions to guide clinical practice and offer a reference for the diagnosis and treatment of cancer. With this background in mind, a metaanalysis was carried out.

\section{Methods}

\subsection{Patients and material}

Serum complements concentrations were measured in 30 normal, apparently healthy donors and 84 lung cancer patients; 44 were male, 40 females, range 35-76 years old. Cancer patients who were presented to the Affiliated Hospital of Medical College, Qingdao University, Wendeng Municipal Hospital and Weihai People's Hospital were included in the study, which resided in Qingdao and Weihai, China. The serum of 30 healthy people who passed the physical examination was collected from Nan'ao People's Hospital, Dapeng New District, Shenzhen. Each control group received written informed consent and matched cancer patients according to gender, age and living area. The criteria for inclusion in the study were pathologically confirmed cancers and well-documented data of the disease. About $5 \mathrm{ml}$ of venous blood samples were obtained from participants who agreed to their participation in the study. The blood sample was allowed to stand overnight at room temperature, allowed to coagulate and centrifuged at $3000 \mathrm{rpm}$ for 10 minutes. The serum was collected in Eppendorf tubes and stored at $4{ }^{\circ} \mathrm{C}$ for 24 hours and the concentration of C3 was detected by using complement C3 ELISA assay kit [Human Complement C3 ELISA Kit (ab108822)] according to the instructions.

\subsection{Ethics statement}

This project of our clinical concentration analysis approved by the ethics committees of the Affiliated Hospital of the Qingdao University, Weihai People's Hospital in Qingdao and Dapeng New District Nan'ao People's Hospital of Shenzhen, China, respectively. The purpose of the study and the procedures used in the study were explained to all participants, and written informed consent was obtained. All serum samples analyzed in our case-control study was provided voluntarily by the participants.

\subsection{Data sources and search strategy}

In order to observe the most relevant articles, databases including PubMed, Embase, The Chorane Library and Google Scholar were searched systematically to determine relevant research published as of September 2019. Medical subject words and freetext words were used in searches investigations in searches to ensure that the searches results were comprehensive. The search process used the following keywords: ("Cancer" or "Cancers" or "Neoplasm"or "Neoplasia" or "Tumor" or "Tumors" or "Malignancy" or "Neoplasia" or "Maligant Neoplasms" or "Malignant Neoplasm") and ("C3" or "Complement 3" or 
"C3,Complement" or "Complement Component 3" or "Component 3,Complement" or "Complement, C3" or "Pro-C3" or "Pro C3" or "C3 Precursor, complement" or "C3 Precursor" or "Precursor, C3" or "Pro-Complement 3" or "Pro Complement 3"). The two researchers independently completed the search strategy and evaluated the titles and abstracts of all articles according to the subsequent eligibility criteria.

\subsection{Study inclusion and exclusion criteria}

In our meta-analysis, the following inclusion criteria were considered: (1) Cancer patients included in the study must be diagnosed and confirmed as cancer patients, (2) the control group must be healthy people, (3) the original data of serum complement C3 concentration is provided.

The standard of exclusion criteria include (1) reviews and abstract articles, (2) gene studies, (3) studies on mass spectrometry and proteomics, (4) animal models studies, (5) studies did not provide the raw data of C3, (6) the concentration of C3 is not from the serum, (7) Studies without control group, (8) the molecule studied is the study of C3 downstream molecules (C3a, C3d, and C3b).

The qualified papers were carefully investigated and the data were extracted. Standardized data extraction was utilized to process the data. If the opinions of the two researchers are not uniform, a discussion will be held to reach an agreement. The information extracted from each study was as follows: the name of the first author, geographic location, publication year, the numbers of experimental and control groups, p-value, type of cancer, and diagnostic method.

Newcastle-Ottawa scale was designed to assess the quality of non-randomized studies in meta-analysis [17]. The score range of our studies is 0 to 9 point, where 0 to 4 points is considered a low-quality research, and from 5 to 9 points is a high-quality research [18]. Two authors independently extracted data and rated each study for quality. A consensus was reached through discussion to resolve differences and was reinforced by author (Zi-Guo Yuan).

\subsection{Statistical analysis}

The results of $\mathrm{C} 3$ concentration were presented as mean \pm SD and the level of lung cancer patients was compared with that of healthy controls by t-test (SPSS22.0 software). Statistical meta-analysis was performed using Revman (version 5.3.0) and Stata (version 12.0; Cochrane collaboration) according to the PRISMA guidelines for performing this meta-analysis [19]. Forest plots were used to visualize the results of each study and the heterogeneity among studies, which were used to calculate and prepare it. Evaluation was carried out of the association between the cancer patients and C3 concentrations by standardized mean difference (SMD) and its $95 \%$ confidence interval (Cls). The heterogeneity was predicted and statistical methods with $\mathrm{I}^{2}$ and Cochrane $Q$ (represented as $\chi 2$ and $p$-value) statistics were used to quantify the variations. For pooling estimates, a fixed effect meta-analysis was conducted on our studies.

In our studies, subgroup including cancer type, publication year, diagnostic method, geographic location, different score of quality and different p-value for the difference of $\mathrm{C} 3$ concentrations between the cancer patients and healthy control was performed to analysis and identify the possible sources of heterogeneity. Furthermore, sensitivity analysis was carried out by eliminating one study at a time using analysis software, and bias was evaluated by the "Begg test" and "Egger test". If the pvalue $<0.05$ was obtained, statistical significance would be achieved.

\section{Results}

\subsection{Literature search results}

Based on the literature search strategies, we initially got 2647 articles. After elimination of duplication, we screened the abstracts of 2614 articles. We closely read the full text of 171 articles, excluding 157 based on the criteria which were mentioned above. Finally, 10 articles including 18 studies published between 1976 and 2006 with 744 cancer patients and 528 healthy controls were considered eligible and were incorporated into the meta-analysis [20];[21];[22];[23];[24];[25];[26]; [27];[28]; 
[29]. After joining research of our own (named Yang ZP, 2020), the characteristics of 19 studies included in the present metaanalysis are shown in Table 1. Figure 1 shows a flow-process diagram for selecting the studies involved. 
Table 1

Study characteristics of the meta-analysis of C3 concentrations in cancer patients.

\begin{tabular}{|c|c|c|c|c|c|c|c|c|c|}
\hline \multirow[t]{2}{*}{ Study } & \multirow[t]{2}{*}{ Year } & \multirow[t]{2}{*}{ Country } & \multicolumn{2}{|l|}{$\begin{array}{l}\text { Cancer } \\
\text { patients }\end{array}$} & \multicolumn{2}{|c|}{ Healthy control } & \multirow{2}{*}{$\begin{array}{l}\text { Type of } \\
\text { cancer }\end{array}$} & \multirow{2}{*}{$\begin{array}{l}\mathrm{p} \text { - } \\
\text { value }\end{array}$} & \multirow[t]{2}{*}{ Method } \\
\hline & & & $\begin{array}{l}\text { C3 } \\
\text { (mean } \\
\pm \text { SD) }\end{array}$ & $\begin{array}{l}\text { Sample } \\
\text { size }\end{array}$ & $\begin{array}{l}\text { C3 } \\
\text { (mean } \\
\pm S D \text { ) }\end{array}$ & $\begin{array}{l}\text { Sample } \\
\text { size }\end{array}$ & & & \\
\hline Bozzetti F & 1982 & Italy & $\begin{array}{l}118.22 \\
\pm 24.17\end{array}$ & 23 & $\begin{array}{l}109.65 \\
\pm 24.95\end{array}$ & 34 & $\begin{array}{l}\text { Digestive } \\
\text { cancer }\end{array}$ & $\begin{array}{l}P>0 . \\
05\end{array}$ & $\begin{array}{l}\text { single radial } \\
\text { immune } \\
\text { diffusion }\end{array}$ \\
\hline $\begin{array}{l}\text { Bozzetti F } \\
2\end{array}$ & 1982 & Italy & $\begin{array}{l}108.17 \\
\pm 24.5\end{array}$ & 29 & $\begin{array}{l}109.65 \\
\pm 24.95\end{array}$ & 34 & Breast cervix & $\begin{array}{l}P>0 . \\
05\end{array}$ & $\begin{array}{l}\text { single radial } \\
\text { immune } \\
\text { diffusion }\end{array}$ \\
\hline $\begin{array}{l}\text { Bozzetti F } \\
3\end{array}$ & 1982 & Italy & $\begin{array}{l}108.04 \\
\pm 28.69\end{array}$ & 26 & $\begin{array}{l}109.65 \\
\pm 24.95\end{array}$ & 34 & $\begin{array}{l}\text { Digestive } \\
\text { cancer }\end{array}$ & $\begin{array}{l}P>0 . \\
05\end{array}$ & $\begin{array}{l}\text { single radial } \\
\text { immune } \\
\text { diffusion }\end{array}$ \\
\hline $\begin{array}{l}\text { Bozzetti F } \\
4\end{array}$ & 1982 & Italy & $\begin{array}{l}107.54 \\
\pm 22.61\end{array}$ & 11 & $\begin{array}{l}109.65 \\
\pm 24.95\end{array}$ & 34 & Breast cervix & $\begin{array}{l}P>0 . \\
05\end{array}$ & $\begin{array}{l}\text { single radial } \\
\text { immune } \\
\text { diffusion }\end{array}$ \\
\hline Chang WY & 1988 & $\begin{array}{l}\text { Republic } \\
\text { of China }\end{array}$ & $\begin{array}{l}113 \pm \\
28.8\end{array}$ & 20 & $\begin{array}{l}87 \pm \\
16.2\end{array}$ & 20 & $\begin{array}{l}\text { Digestive } \\
\text { cancer }\end{array}$ & $\mathrm{P} \otimes 0.05$ & nephelometry \\
\hline \multirow[t]{2}{*}{ Study } & \multirow[t]{2}{*}{ Year } & \multirow[t]{2}{*}{ Country } & \multicolumn{2}{|l|}{$\begin{array}{l}\text { Cancer } \\
\text { patients }\end{array}$} & \multicolumn{2}{|c|}{ Healthy control } & $\begin{array}{l}\text { Type of } \\
\text { cancer }\end{array}$ & $\begin{array}{l}\mathrm{p}- \\
\text { value }\end{array}$ & Method \\
\hline & & & $\begin{array}{l}\text { C3 } \\
\text { (mean } \\
\pm \text { SD) }\end{array}$ & $\begin{array}{l}\text { Sample } \\
\text { size }\end{array}$ & $\begin{array}{l}\text { C3 } \\
\text { (mean } \\
\pm \mathrm{SD} \text { ) }\end{array}$ & $\begin{array}{l}\text { Sample } \\
\text { size }\end{array}$ & & & \\
\hline Fust G & 1985 & Hungary & $\begin{array}{l}122.6 \pm \\
52.6\end{array}$ & 85 & $\begin{array}{l}125.5 \\
\pm 27.5\end{array}$ & 65 & Leukaemia & $\begin{array}{l}P>0 . \\
05\end{array}$ & $\begin{array}{l}\text { single radial } \\
\text { immune } \\
\text { diffusion }\end{array}$ \\
\hline $\begin{array}{l}\text { HUMLOVÁ } \\
\text { Z }\end{array}$ & 2006 & Czech & $\begin{array}{l}101 \pm \\
19.0\end{array}$ & 24 & $\begin{array}{l}95.0 \pm \\
16.0\end{array}$ & 24 & $\begin{array}{l}\text { Chronic } \\
\text { Myeloid } \\
\text { Leukaemia. }\end{array}$ & $\begin{array}{l}P>0 . \\
05\end{array}$ & nephelometry \\
\hline $\begin{array}{l}\text { Janssen } \\
\text { CW }\end{array}$ & 1983 & Czech & $\begin{array}{l}89.6 \pm \\
15.8\end{array}$ & 11 & $\begin{array}{l}91.0 \pm \\
16.0\end{array}$ & 100 & $\begin{array}{l}\text { Digestive } \\
\text { cancer }\end{array}$ & $\begin{array}{l}P>0 . \\
05\end{array}$ & $\begin{array}{l}\text { single radial } \\
\text { immune } \\
\text { diffusion }\end{array}$ \\
\hline $\begin{array}{l}\text { Janssen } \\
\text { CW } 2\end{array}$ & 1983 & Czech & $\begin{array}{l}92.7 \pm \\
20.4\end{array}$ & 36 & $\begin{array}{l}91.0 \pm \\
16.0\end{array}$ & 100 & $\begin{array}{l}\text { Digestive } \\
\text { cancer }\end{array}$ & $\begin{array}{l}P>0 . \\
05\end{array}$ & $\begin{array}{l}\text { single radial } \\
\text { immune } \\
\text { diffusion }\end{array}$ \\
\hline $\begin{array}{l}\text { Janssen } \\
\text { CW } 3\end{array}$ & 1983 & Czech & $\begin{array}{l}94.7 \pm \\
26.5\end{array}$ & 37 & $\begin{array}{l}91.0 \pm \\
16.0\end{array}$ & 100 & $\begin{array}{l}\text { Digestive } \\
\text { cancer }\end{array}$ & $\begin{array}{l}P>0 . \\
05\end{array}$ & $\begin{array}{l}\text { single radial } \\
\text { immune } \\
\text { diffusion }\end{array}$ \\
\hline $\begin{array}{l}\text { Janssen } \\
\text { CW } 4\end{array}$ & 1983 & Czech & $\begin{array}{l}99.1 \pm \\
24.3\end{array}$ & 84 & $\begin{array}{l}91.0 \pm \\
16.0\end{array}$ & 100 & $\begin{array}{l}\text { Digestive } \\
\text { cancer }\end{array}$ & $\begin{array}{l}P>0 . \\
05\end{array}$ & $\begin{array}{l}\text { single radial } \\
\text { immune } \\
\text { diffusion }\end{array}$ \\
\hline
\end{tabular}

Note: SD-standard deviation, Cl-Confidence Interval, P-p-value, C3-Complement Component 3, ELISA-Enzyme-linked immunosorbent assay

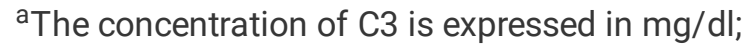

${ }^{b}$ Statistically, the $p$-value obtained by the significance test method is generally significant at $P<0.05$ in t-test, which means that the probability of differences between samples due to sampling errors is less than 0.05 . 


\begin{tabular}{|c|c|c|c|c|c|c|c|c|c|}
\hline Study & Year & Country & \multicolumn{2}{|l|}{$\begin{array}{l}\text { Cancer } \\
\text { patients }\end{array}$} & \multicolumn{2}{|c|}{ Healthy control } & $\begin{array}{l}\text { Type of } \\
\text { cancer }\end{array}$ & $\begin{array}{l}\mathrm{p}- \\
\text { value }\end{array}$ & Method \\
\hline \multirow[t]{2}{*}{ Study } & \multirow[t]{2}{*}{ Year } & \multirow[t]{2}{*}{ Country } & \multicolumn{2}{|l|}{$\begin{array}{l}\text { Cancer } \\
\text { patients }\end{array}$} & \multicolumn{2}{|c|}{ Healthy control } & \multirow[t]{2}{*}{$\begin{array}{l}\text { Type of } \\
\text { cancer }\end{array}$} & \multirow[t]{2}{*}{$\begin{array}{l}\mathrm{p} \text { - } \\
\text { value }\end{array}$} & \multirow[t]{2}{*}{ Method } \\
\hline & & & $\begin{array}{l}\text { C3 } \\
\text { (mean } \\
\pm \text { SD) }\end{array}$ & $\begin{array}{l}\text { Sample } \\
\text { size }\end{array}$ & $\begin{array}{l}\text { C3 } \\
\text { (mean } \\
\pm S D)\end{array}$ & $\begin{array}{l}\text { Sample } \\
\text { size }\end{array}$ & & & \\
\hline Minh DQ & 1983 & Hungary & $\begin{array}{l}139 \pm \\
43.1\end{array}$ & 41 & $\begin{array}{l}125 \pm \\
27.5\end{array}$ & 65 & Leukaemia & $\mathrm{P} \otimes 0.05$ & $\begin{array}{l}\text { Single radial } \\
\text { immune } \\
\text { diffusion }\end{array}$ \\
\hline Oner F & 2004 & Turkey & $\begin{array}{l}110.0 \pm \\
87.0\end{array}$ & 10 & $\begin{array}{l}103.0 \\
\pm 59.0\end{array}$ & 22 & Lung Cancer & $\mathrm{P} \otimes 0.05$ & $\begin{array}{l}\text { Single radial } \\
\text { immune } \\
\text { diffusion }\end{array}$ \\
\hline Oner F 2 & 2004 & Turkey & $\begin{array}{l}107.0 \pm \\
55.0\end{array}$ & 24 & $\begin{array}{l}103.0 \\
\pm 59.0\end{array}$ & 22 & Lung Cancer & $P \rrbracket 0.05$ & $\begin{array}{l}\text { Single radial } \\
\text { immune } \\
\text { diffusion }\end{array}$ \\
\hline $\begin{array}{l}\text { Verhaegen } \\
\mathrm{H}\end{array}$ & 1976 & Belgium & $\begin{array}{l}93.53 \pm \\
23.51\end{array}$ & 197 & $\begin{array}{l}81.85 \\
\pm 12.17\end{array}$ & 85 & Other & $\mathrm{P} \otimes 0.05$ & $\begin{array}{l}\text { Single radial } \\
\text { immune } \\
\text { diffusion }\end{array}$ \\
\hline Varga L & 1995 & Hungary & $\begin{array}{l}132 \pm \\
58\end{array}$ & 28 & $\begin{array}{l}125.5 \\
\pm 27.5\end{array}$ & 65 & $\begin{array}{l}\text { Chronic } \\
\text { Lymphocytic } \\
\text { leukaemia }\end{array}$ & $\begin{array}{l}P>0 \\
05\end{array}$ & $\begin{array}{l}\text { Single radial } \\
\text { immunodiffusion }\end{array}$ \\
\hline Heier HE & 1978 & Norway & $\begin{array}{l}108.7 \pm \\
36.9\end{array}$ & 27 & $\begin{array}{l}84.0 \pm \\
18.3\end{array}$ & 48 & $\begin{array}{l}\text { Hodgkin's } \\
\text { Disease }\end{array}$ & $\mathrm{P} \otimes 0.05$ & $\begin{array}{l}\text { Single radial } \\
\text { immune } \\
\text { diffusion }\end{array}$ \\
\hline Heier HE 2 & 1978 & Norway & $\begin{array}{l}97.9 \pm \\
31.0\end{array}$ & 31 & $\begin{array}{l}84.0 \pm \\
18.3\end{array}$ & 48 & Other & $\begin{array}{l}P>0 \\
05\end{array}$ & $\begin{array}{l}\text { Single radial } \\
\text { immune } \\
\text { diffusion }\end{array}$ \\
\hline Yang ZP & 2020 & China & $\begin{array}{l}107.49 \\
\pm 33.83\end{array}$ & 84 & $\begin{array}{l}95.29 \\
\pm 17.29\end{array}$ & 30 & Lung Cancer & $\mathrm{P} \otimes 0.05$ & ELISA \\
\hline \multicolumn{10}{|c|}{$\begin{array}{l}\text { Note: SD-standard deviation, Cl-Confidence Interval, P-p-value, C3-Complement Component 3, ELISA-Enzyme-linked } \\
\text { immunosorbent assay }\end{array}$} \\
\hline \multicolumn{10}{|c|}{ 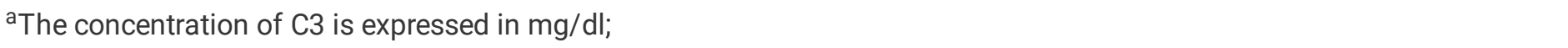 } \\
\hline
\end{tabular}

\subsection{Quality assessment}

Table 2 lists the quality of the articles included. The total score of nine articles was assessed at score $\geq 5$ points, and two articles were assessed at score $<5$ points. The average score of the study is higher than 6 points. 
Table 2

Quality assessment of the studies included in our meta-analysis.

\begin{tabular}{|c|c|c|c|c|c|c|c|c|c|c|c|}
\hline \multirow[t]{2}{*}{ No } & \multirow[t]{2}{*}{ first author } & \multicolumn{9}{|c|}{ Quality Indicators from Newcastle-Ottawa scale } & \multirow[t]{2}{*}{ Total score } \\
\hline & & 1 & 2 & 3 & 4 & $5 \mathrm{~A}$ & 5B & 6 & 7 & 8 & \\
\hline 1 & Bozzetti F, 1982 & YES & NO & NO & YES & YES & YES & YES & YES & NO & 6 \\
\hline 2 & Janssen CW, 1983 & NO & YES & YES & NO & YES & NO & YES & YES & NO & 5 \\
\hline 3 & Chang WY, 1988 & YES & YES & YES & NO & YES & NO & NO & YES & YES & 5 \\
\hline 4 & Fust G, 1985 & NO & YES & YES & NO & YES & NO & NO & YES & NO & 4 \\
\hline 5 & Verhaegen H, 1976 & NO & NO & NO & YES & YES & YES & YES & YES & YES & 6 \\
\hline 6 & Minh D Q, 1983 & NO & YES & NO & YES & YES & NO & NO & NO & YES & 4 \\
\hline 7 & Oner F, 2004 & YES & YES & NO & YES & YES & NO & YES & NO & YES & 6 \\
\hline 8 & Varga L, 1995 & YES & YES & NO & NO & YES & YES & NO & YES & NO & 5 \\
\hline 9 & HUMLOVÁ Z, 2006 & YES & NO & YES & NO & YES & NO & NO & YES & NO & 5 \\
\hline 10 & Heier HE, 1978 & YES & YES & NO & NO & YES & YES & YES & YES & YES & 7 \\
\hline 11 & Yang ZP, 2020 & YES & YES & YES & YES & YES & NO & YES & NO & NO & 6 \\
\hline \multicolumn{12}{|c|}{ Note: No-number, C3-Complement component 3} \\
\hline
\end{tabular}

\subsection{Association between cancer patients and C3 concentration}

The results of our clinical data show that the $\mathrm{C} 3$ levels of lung cancer patients were significantly higher than healthy control $(1.07 \pm 0.34 \mathrm{~g} / \mathrm{l}, 0.95 \pm 0.17 \mathrm{~g} / \mathrm{l}$ respectively, which keep two decimal places after the decimal point); The $\mathrm{p}$-value for t-test was $0.014)$, Table 3.

Table 3

Results of C3 concentrations determination and comparison between lung cancer patients and healthy.

\begin{tabular}{|lcccc|}
\hline Group & $\mathbf{N}$ & $\mathbf{C 3}($ mean \pm SD);g/l & t & P \\
\hline Lung cancer & 84 & $1.075 \pm 0.338$ & 2.510 & 0.014 \\
\hline Healthy control & 30 & $0.953 \pm 0.173$ & & \\
\hline \multicolumn{4}{|l}{ Note: P-p-value, N-Number, SD-Standard Deviation, t-value of t in t-test } \\
\hline
\end{tabular}

For meta-analysis, nineteen studies were incorporated into the analysis of the correlation between serum C3 levels in the cancer patients with healthy controls. As shown in Fig. 2, the results were expressed in terms of standardized mean difference (SMD) and the corresponding 95\% confidence interval. Heterogeneity exists in our results, but it is relatively acceptable $\left(X^{2}=31.84\right.$, $p$-value $\left.=0.02,1^{2}=43 \%\right)$, so that, the fixed effect model was used. In regard to the association between the cancer patients and serum C3 concentration, the results suggested that the SMD was $0.30(95 \% \mathrm{Cl}=0.20$ to $0.40, Z=5.95, p$-value $<$ 0.00001 ), which is statistically significant and shows that the serum concentration of cancer patients is higher than the healthy control.

\subsection{The subgroup analysis}


All forest plots for all subgroup analyses were provided in supplementary materials.

We did subgroup analysis based on different types of cancer to evaluate whether the variation would affect the results. Except for the breast cancer subgroup (SMD: $-0.07,95 \% \mathrm{Cl}=-0.47$ to $0.33, \mathrm{Z}=0.33$, $\mathrm{p}$-value $=0.74$ ), the data showed that the $\mathrm{C} 3$ level of different types of patients is higher than that of the healthy population. The fluctuation range of $\mathrm{I}^{2}$ values is not large, so the consequence of our results is relatively stable.

We conducted subgroup analysis based on different diagnostic methods. The heterogeneity detected by nephelometry $\left(X^{2}=2.83, I^{2}=65 \%\right.$, SMD: $0.65,95 \% \mathrm{Cl}=0.22$ to 1.09$)$ and single radial immuno-diffusion method $\left(\chi^{2}=26.01, I^{2}=42 \otimes\right.$, SMD: 0.27 , $95 \% \mathrm{Cl}=0.17$ to 0.38 ) are both relatively high and the difference between them is large. So different diagnostic method is an important factor for heterogeneity.

In subgroup analysis based on different publication year, the difference of C3 concentration between the cancer group and healthy controls is significant in the studies published before 2000 and the heterogeneity is relatively high $\left(\chi^{2}=30.72, l^{2}=54 \%\right.$, SMD: $0.30,95 \% \mathrm{Cl}=0.20$ to $0.41, Z=5.63$, $p$-value $<0.00001$ ), while such trend not such obviously found in the studies published after $2000\left(\chi^{2}=1.07, I^{2}=0 \bigotimes, S M D: 0.27,95 \% C l=0.00\right.$ to $0.54, Z=1.96, p$-value $\left.=0.05\right)$. Analysis proved that publication year may affect the heterogeneity as well as the results of our analysis.

We conducted subgroup analysis depending on different geographic location. In the Asia group, concentrations of C3 in cancer patients were higher than healthy control $\left(X^{2}=5.97, I^{2}=50 \%\right.$, SMD: $0.40,95 \% \mathrm{Cl}: 0.12$ to $0.68, Z=2.80$, $p$-value $=0.005$. In the Europe group, the increasing trend was more significant $\left(\chi^{2}=25.31, l^{2}=45 \rrbracket, S M D: 0.29,95 \% \mathrm{Cl}: 0.18\right.$ to $0.39, Z=5.31, p$-value $<$ 0.00001). However, there was no significant difference in heterogeneity between the two subgroups. So, it proved that the impact of geographic location on the results is not critical.

We also conducted subgroup analysis depending on different score of quality evaluation. In the " $\geq 5$ " score group, the heterogeneity was significant $\left(\chi^{2}=19.82, l^{2}=55 \%\right.$, SMD: $0.42,95 \% \mathrm{Cl}=0.27$ to $0.56, Z=5.78, p$-value $\left.<0.00001\right)$, while heterogeneity was not found in the group " $>5$ " ( $\chi^{2}=6.97, I^{2}=0 \rrbracket, S M D: 0.19,95 \% \mathrm{Cl}=0.05$ to $0.33, Z=2.67, p$-value $\left.=0.008\right)$, which demonstrated that the score of quality evaluation of studies was one of the sources of heterogeneity.

Furthermore, we carried out subgroup analysis based on different p-value for the difference of C3 concentrations between the cancer patients and healthy control. The heterogeneity was not particularly high in group " $p$-value $<0.05$ " $\left(\chi^{2}=9.63, I^{2}=38 \%\right.$, SMD: $0.52,95 \% \mathrm{Cl}=0.36$ to $0.68, Z=6.29$, p-value $<0.00001)$, while heterogeneity was not found in group ">0.05" $\left(\chi^{2}=11.00\right.$, $I^{2}=0 \bigotimes, S M D: 0.17,95 \% \mathrm{Cl}=0.05$ to $0.29, Z=2.67, p$-value $=0.008$ ). Interestingly, although the size of $p$-value in the original data was in contradiction, the results showed that the serum C3 concentrations of cancer patients were significantly higher than that of healthy people. The "p-value" had little effect on heterogeneity because their heterogeneity was within the acceptable range.

\subsection{The Publication bias assessment}

Our finding shows no significant publication bias was existed (Fig. 3). Furthermore, both Begg and Egger tests show that no publication bias exists in this study $(P=0.529$ and 0.551 , respectively). Sensitivity analysis of serum C3 concentration showed that the combined results did not change after repeating our model with excluding one study each time, Fig. 4.

\section{Discussion}

To our best knowledge, this is the first meta-analysis study assessing the concentrations of serum C3 levels in cancer patients with the objective of assessment of the role of $\mathrm{C} 3$ in the development and progression of cancer. Our results showed that the serum C3 concentrations in cancer patients were significantly higher than that of healthy people in the control group. Additionally, we made an analysis of the serum C3 concentrations in 84 lung cancer patients and 30 healthy people, which could be merged into our meta-analysis and support the conclusions. 
The function of complement is to detect, mark and eliminate the invasion of microorganism with almost immediate reaction but with enough specificity, so as to prevent damage to the host cell [30,31]. Complement is generally thought to prevent tumor formation, but it is often affected by certain conditions and is currently considered to be a major obstacle to the success of antibody immunotherapy [16]. The complement system suppresses tumorigenesis by promoting the acute inflammation and tumor cell lysis; Instead, it promotes tumor growth by stimulating chronic inflammation, immuno-suppression, and angiogenesis [32].

Day after another, more research is providing a strong evidence that C3 can affect the occurrence and development of cancer. For instance, it is reported that the increase of plasma C3 level in patients with lung cancer is a function of the shortening of the survival period of patients with cancer [33,34]. Interestingly, studies have found that the growth and metastasis of primary tumors in mice lacking $\mathrm{C} 3$ are strongly inhibited. This is evident by increasing the number of IFN- $\gamma+/ T N F-a+/ I L-10+C D 4+$ and CD8 + T cells and that C3-deficient mice have a T cell and IL-10 dependence on tumor development $[35,36]$. In a mouse model of epithelial ovarian cancer, a genetic C3 deficiency can also impair tumor vascularization by altering the function of endothelial cells [37]. It is hypothesized that cancer metastasis is the cause of death in approximately $90 \%$ of cancer patients [38]. Moreover, the neoplastic transformation is enhanced by the ability of malignant cells to activate the complement C3, which may be involved in the process of cancer metastasis [38]. What's more, study showed that C3 plays an important role in the immunosurveillance and earlier cancer metastasis [39].

Some attempts have been made to determine whether serum C3 levels are closely related to the rapeutic effect and prognosis of cancer. A number of researchers have reported that multiple tumors can significantly improve C3/C3a levels in the cell experiments or animal models, including cases with breast cancer, lung cancer, ovarian cancer, rectal cancer and liver cancer [40];[41]; [36, 42, 43]. Experimentally, it was reported that complement C3 can be considered as an early diagnostic marker for some type of cancers $[40,44,45]$. The above described research supports the results of our meta-analysis from different angles, indicating that our analytical results are reliable.

We made an analysis of the serum C3 concentrations in 84 lung cancer patients and 30 healthy people, which not only could be merged into our meta-analysis as an advanced research but also support the conclusions of our meta-analysis. Then, we carried out a meta-analysis of 19 studies regarding the serum C3 concentrations of cancer patients. Our analysis suggested that there is a significantly increased concentration of C3 in the cancer patient's serum or plasma compared to healthy controls. This phenomenon may suggest that C3 concentration of complement may be a marker of cancer patients at a certain period, or C3 may be considered as a new guideline for cancer prevention and treatment. Therefore, it is necessary for researchers to carry out experiments, further exploration and discovery.

As mentioned earlier, numerous studies support the results of our meta-analysis revealing that our research is well founded. We had to admit that our research is heterogeneous. Hence, we performed subgroup analysis and sensitivity analysis in details to explore and discuss the potential sources of heterogeneity as far as possible. Fortunately, the results showed that our research results are relatively stable.

The presented data of meta-analysis are originating from previous studies, which measured the C3 concentrations clinically starting with the original assay and raw data in order to provide support, reference and comparison for C3 concentration data from various bodies of scientific research. Since the systematic clinical study of serum C3 in cancer patients is more inclined to mass spectrometry and proteomics, or to animal experiments and cell models, the data are relatively difficult to collect, and relatively old.

The reported meta-analysis in our study has several advantages. Firstly, to our best knowledge, this is the first meta-analysis study assessing the concentrations of serum C3 levels in cancer patients with the objective of assessment of the role of C3 in the development and progression of cancer, which can provide more data for the clinic. More importantly, it can provide a comparison and reference for data analysis and experimental conclusions about cancer patients C3. Secondly, we measured and compared the serum C3 concentrations of lung cancer patients and healthy people in clinical and also included its serum data into meta-analysis. Fortunately, our clinical data analysis results and our meta-analysis results support and confirm each 
other. What's more, among the data collected by the meta-analysis, there is not any study on the determination of C3 by ELISA so our clinical study increased the stability of the conclusion. Next, in our meta-analysis, we conducted a detailed subgroup analysis to explain the source of heterogeneity and its possible impact on the results. Finally, in our meta-analysis, there is no positive evidence of publication bias and the sensitivity analyses were performed which results did not achieve statistical significance.

On the other side, our study has inherent limitations. First, the number of articles and studies involved in our meta-analysis is insufficient, and the publication year is old. The reason for this limit is related to the human method of studying the serum C3 level of cancer patients and the individual method of searching for literature, which may lead to an insufficient sample size and amount of data (the type of cancer is not comprehensive enough; the numbers in the control and experimental groups is not large enough). Therefore, if we want to obtain more accurate and reliable conclusions, it is necessary to analyze the data of others and undertake large-scale retrospective research. Secondly, in addition to the concentrations of serum C3 in cancer patients, there are indicators (such as $\mathrm{CH} 50$ ) cannot be included in our meta-analysis due to the different units of concentration. Finally, the quality evaluation is not particularly satisfactory, which should be improved in future studies.

\section{Conclusions}

The current research shows that the serum C3 concentrations of cancer patients is significantly higher than that of healthy people suggesting that C3 may be an effective biomarker for cancer diagnosis. According to the different measurement methods, cancer types and diagnostic performance are also different. However, further well-designed, large-scale, randomized controlled trials are needed to confirm this conclusion.

\section{Abbreviations}

C3

Complement Component 3

SMD

Standardized mean difference

Cls

Confidence intervals

MAC

Membrane attack complex

STATA

Statistics and data

SD

Standard Deviation

SE

standard error

ELISA

Enzyme-linked immunosorbent assay

T-test

Student's t test

\section{Declarations}

\section{Ethics approval and consent to participate}

This project of our clinical concentration analysis approved by the ethics committees of the Affiliated Hospital of the Qingdao University, Weihai People's Hospital in Qingdao and Dapeng New District Nan'ao People's Hospital of Shenzhen, China, respectively. The purpose of the study and the procedures used in the study were explained to all participants, and written 
informed consent was obtained. All serum samples analyzed in our case-control study was provided voluntarily by the participants.

\section{Consent for publication}

Not applicable

\section{Availability of data and materials}

All data generated or analyzed during this study are included in this published article.

\section{Competing interests}

The authors declare that they have no competing interests.

\section{Funding}

This work was supported, in part, by grants from the Key Research and Development Programme of Guangdong Province (2019B020218004), National Natural Science Foundation of China (31972707), the Natural Science Foundation of Guangdong Province (2019A1515011534), Major Scientific Research Projects (Characteristic Innovation) of Guangdong Province (2017KTSCX018), Natural Science Foundation of Guangdong Province (2017A030313094). None of the funding bodies had any part in the design of the study and collection, analysis, interpretation of data and in writing the manuscript.

\section{Authors' contributions}

ZPY contributed to the data collection, analysis and the writing of the manuscript. XHW contributed to the drafting of the manuscript. JAH and YSM contributed to the revising of the manuscript. ZWR and XRZ contributed to the data collection and the laboratory work. AQY and WC contributed to the quality evaluation of included articles, and participate in the discussion. ZGY, YSM and XXZ contributed to the conception of the idea, design and revision of the first draft. All authors read and approved the final manuscript.

\section{Acknowledgements}

Not applicable.

\section{References}

1. Bray F, Ferlay J, Soerjomataram I, Siegel RL, Torre LA, Jemal A. Global cancer statistics 2018: GLOBOCAN estimates of incidence and mortality worldwide for 36 cancers in 185 countries. CA Cancer J Clin. 2018;68(6):394-424.

2. Cannon G, Gupta P, Gomes F, Kerner J, Parra W, Weiderpass E, et al. Prevention of cancer and non-communicable diseases. Asian Pac J Cancer Prev. 2012;13 Suppl 4:3-11.

3. Fallahi S, Seyyed Tabaei SJ, Pournia Y, Zebardast N, Kazemi B. Comparison of loop-mediated isothermal amplification (LAMP) and nested-PCR assay targeting the RE and B1 gene for detection of Toxoplasma gondii in blood samples of children with leukaemia. Diagn Microbiol Infect Dis. 2014;79(3):347-54.

4. Islami F, Goding Sauer A, Miller KD, Siegel RL, Fedewa SA, Jacobs EJ, et al. Proportion and number of cancer cases and deaths attributable to potentially modifiable risk factors in the United States. CA Cancer J Clin. 2018;68(1):31-54.

5. Ricklin D, Hajishengallis G, Yang K, Lambris JD. Complement: a key system for immune surveillance and homeostasis. Nat Immunol. 2010;11(9):785-97.

6. Walport MJ. Complement. First of two parts. N Engl J Med. 2001;344(14):1058-66.

7. Spitzer D, Mitchell LM, Atkinson JP, Hourcade DE. Properdin can initiate complement activation by binding specific target surfaces and providing a platform for de novo convertase assembly. J Immunol. 2007;179(4):2600-8. 
8. Kemper C, Atkinson JP, Hourcade DE. Properdin: emerging roles of a pattern-recognition molecule. Annu Rev Immunol. 2010;28:131-55.

9. Imai M, Landen C, Ohta R, Cheung NK, Tomlinson S. Complement-mediated mechanisms in anti-GD2 monoclonal antibody therapy of murine metastatic cancer. Cancer Res. 2005;65(22):10562-8.

10. Ehlenberger AG, Nussenzweig V. The role of membrane receptors for C3b and C3d in phagocytosis. J Exp Med. 1977;145(2):357-71.

11. Perlmann H, Perlmann P, Schreiber RD, Muller-Eberhard HJ. Interaction of target cell-bound C3bi and C3d with human lymphocyte receptors. Enhancement of antibody-mediated cellular cytotoxicity. J Exp Med. 1981;153(6):1592-603.

12. Schmidt CQ, Lambris JD, Ricklin D. Protection of host cells by complement regulators. Immunol Rev. 2016;274(1):152-171.

13. Ricklin D, Mastellos DC, Reis ES, Lambris JD. The renaissance of complement therapeutics. Nat Rev Nephrol. 2018;14(1):26-47.

14. Zhao P, Wu J, Lu F, Peng X, Liu C, Zhou N, et al. The imbalance in the complement system and its possible physiological mechanisms in patients with lung cancer. BMC Cancer. 2019;19(1):201.

15. Ferluga J, Schorlemmer HU, Baptista LC, Allison AC. Cytolytic effects of the complement cleavage product, $\mathrm{C} 3 \mathrm{a}$. $\mathrm{Br} \mathrm{J}$ Cancer. 1976;34(6):626-34.

16. Mamidi S, Hone S, Kirschfink M. The complement system in cancer: Ambivalence between tumour destruction and promotion. Immunobiology. 2017;222(1):45-54.

17. Cota GF, de Sousa MR, Fereguetti TO, Rabello A. Efficacy of anti-leishmania therapy in visceral leishmaniasis among HIV infected patients: a systematic review with indirect comparison. PLoS Negl Trop Dis. 2013;7(5):e2195.

18. Ownby RL, Crocco E, Acevedo A, John V, Loewenstein D. Depression and risk for Alzheimer disease: systematic review, meta-analysis, and metaregression analysis. Arch Gen Psychiatry. 2006;63(5):530-8.

19. Moher D, Shamseer L, Clarke M, Ghersi D, Liberati A, Petticrew M, et al. Preferred reporting items for systematic review and meta-analysis protocols (PRISMA-P) 2015 statement. Syst Rev. 2015;4:1.

20. Heier HE, Carpentier NA, Lambert PH, Godal T. Quantitation of serum complement components and plasma C3d in patients with malignant lymphoma: relation to the stage of the tumor and circulating immune complexes. Int $\mathrm{J}$ Cancer. 1978;21(6):695-9.

21. Varga L, Czink E, Miszlai Z, Paloczi K, Banyai A, Szegedi G, et al. Low activity of the classical complement pathway predicts short survival of patients with chronic lymphocytic leukaemia. Clin Exp Immunol. 1995;99(1):112-6.

22. Verhaegen H, De Cock W, De Cree J, Verbruggen F. Increase of serum complement levels in cancer patients with progressing tumors. Cancer. 1976;38(4):1608-13.

23. Oner F, Savas I, Numanoglu N. Immunoglobulins and complement components in patients with lung cancer. Tuberk Toraks. 2004;52(1):19-23.

24. Minh DQ, Czink E, Mod A, Fust G, Hollan SR. Serial complement measurements in patients with leukaemia. Clin Lab Haematol. 1983;5(1):23-34.

25. Janssen CW, Jr., Tonder O, Matre R. Stage-related correlations between immunoglobulins and complement components in preoperative sera from patients with gastric carcinoma. Eur J Cancer Clin Oncol. 1983;19(11):1601-5.

26. Humlova Z, Klamova H, Janatkova I, Sandova P, Sterzl I, Sobotkova E, et al. Immunological profiles of patients with chronic myeloid leukaemia. I. State before the start of treatment. Folia Biol (Praha). 2006;52(3):47-58.

27. Fust G, Czink E, Minh D, Miszlay Z, Varga L, Hollan SR. Depressed classical complement pathway activities in chronic lymphocytic leukaemia. Clin Exp Immunol. 1985;60(3):489-95.

28. Chang WY, Chuang WL. Complements as new diagnostic tools of hepatocellular carcinoma in cirrhotic patients. Cancer. 1988;62(2):227-32.

29. Bozzetti F, Migliavacca S, Scotti A, Bonalumi MG, Scarpa D, Baticci F, et al. Impact of cancer, type, site, stage and treatment on the nutritional status of patients. Ann Surg. 1982;196(2):170-9. 
30. Ricklin D, Reis ES, Lambris JD. Complement in disease: a defence system turning offensive. Nat Rev Nephrol. 2016;12(7):383-401.

31. Merle NS, Church SE, Fremeaux-Bacchi V, Roumenina LT. Complement System Part I - Molecular Mechanisms of Activation and Regulation. Front Immunol. 2015;6:262.

32. Kolev M, Towner L, Donev R. Complement in cancer and cancer immunotherapy. Arch Immunol Ther Exp (Warsz). 2011;59(6):407-19.

33. Ajona D, Pajares MJ, Corrales L, Perez-Gracia JL, Agorreta J, Lozano MD, et al. Investigation of complement activation product c4d as a diagnostic and prognostic biomarker for lung cancer. J Natl Cancer Inst. 2013;105(18):1385-93.

34. Mehan MR, Ayers D, Thirstrup D, Xiong W, Ostroff RM, Brody EN, et al. Protein signature of lung cancer tissues. PLoS One. 2012;7(4):e35157.

35. Wang Y, Sun SN, Liu Q, Yu YY, Guo J, Wang K, et al. Autocrine Complement Inhibits IL10-Dependent T-cell-Mediated Antitumor Immunity to Promote Tumor Progression. Cancer Discov. 2016;6(9):1022-35.

36. Kwak JW, Laskowski J, Li HY, McSharry MV, Sippel TR, Bullock BL, et al. Complement Activation via a C3a Receptor Pathway Alters CD4(+) T Lymphocytes and Mediates Lung Cancer Progression. Cancer Res. 2018;78(1):143-156.

37. Nunez-Cruz S, Gimotty PA, Guerra MW, Connolly DC, Wu YQ, DeAngelis RA, et al. Genetic and pharmacologic inhibition of complement impairs endothelial cell function and ablates ovarian cancer neovascularization. Neoplasia. 2012;14(11):9941004.

38. Pio R, Corrales L, Lambris JD. The role of complement in tumor growth. Adv Exp Med Biol. 2014;772:229-62.

39. Bandini S, Curcio C, Macagno M, Quaglino E, Arigoni M, Lanzardo S, et al. Early onset and enhanced growth of autochthonous mammary carcinomas in C3-deficient Her2/neu transgenic mice. Oncoimmunology. 2013;2(9):e26137.

40. Chung L, Moore K, Phillips L, Boyle FM, Marsh DJ, Baxter RC. Novel serum protein biomarker panel revealed by mass spectrometry and its prognostic value in breast cancer. Breast Cancer Res. 2014;16(3):R63.

41. Cho MS, Vasquez HG, Rupaimoole R, Pradeep S, Wu S, Zand B, et al. Autocrine effects of tumor-derived complement. Cell Rep. 2014;6(6):1085-1095.

42. Kanmura S, Uto H, Sato Y, Kumagai K, Sasaki F, Moriuchi A, et al. The complement component C3a fragment is a potential biomarker for hepatitis C virus-related hepatocellular carcinoma. J Gastroenterol. 2010;45(4):459-67.

43. Tao S, Haug U, Kuhn K, Brenner H. Comparison and combination of blood-based inflammatory markers with faecal occult blood tests for non-invasive colorectal cancer screening. Br J Cancer. 2012;106(8):1424-30.

44. Wang H, Luo C, Zhu S, Fang H, Gao Q, Ge S, et al. Serum peptidome profiling for the diagnosis of colorectal cancer: discovery and validation in two independent cohorts. Oncotarget. 2017;8(35):59376-59386.

45. Abbritti RV, Polito F, Cucinotta M, Lo Giudice C, Caffo M, Tomasello C, et al. Meningiomas and Proteomics: Focus on New Potential Biomarkers and Molecular Pathways. Cancer Genomics Proteomics. 2016;13(5):369-79.

\section{Figures}




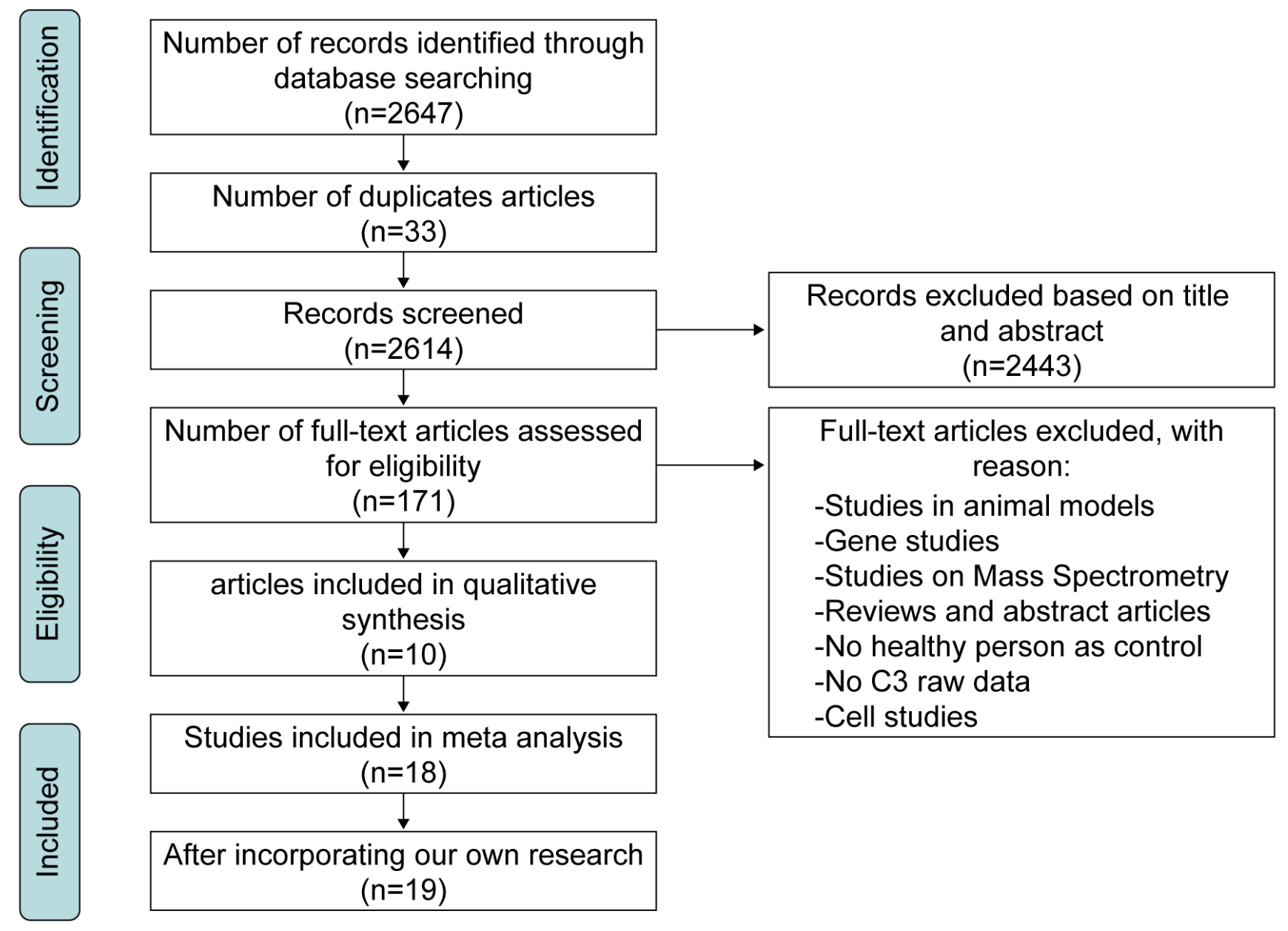

Figure 1

Flow-process diagram of systematic review and meta-analysis

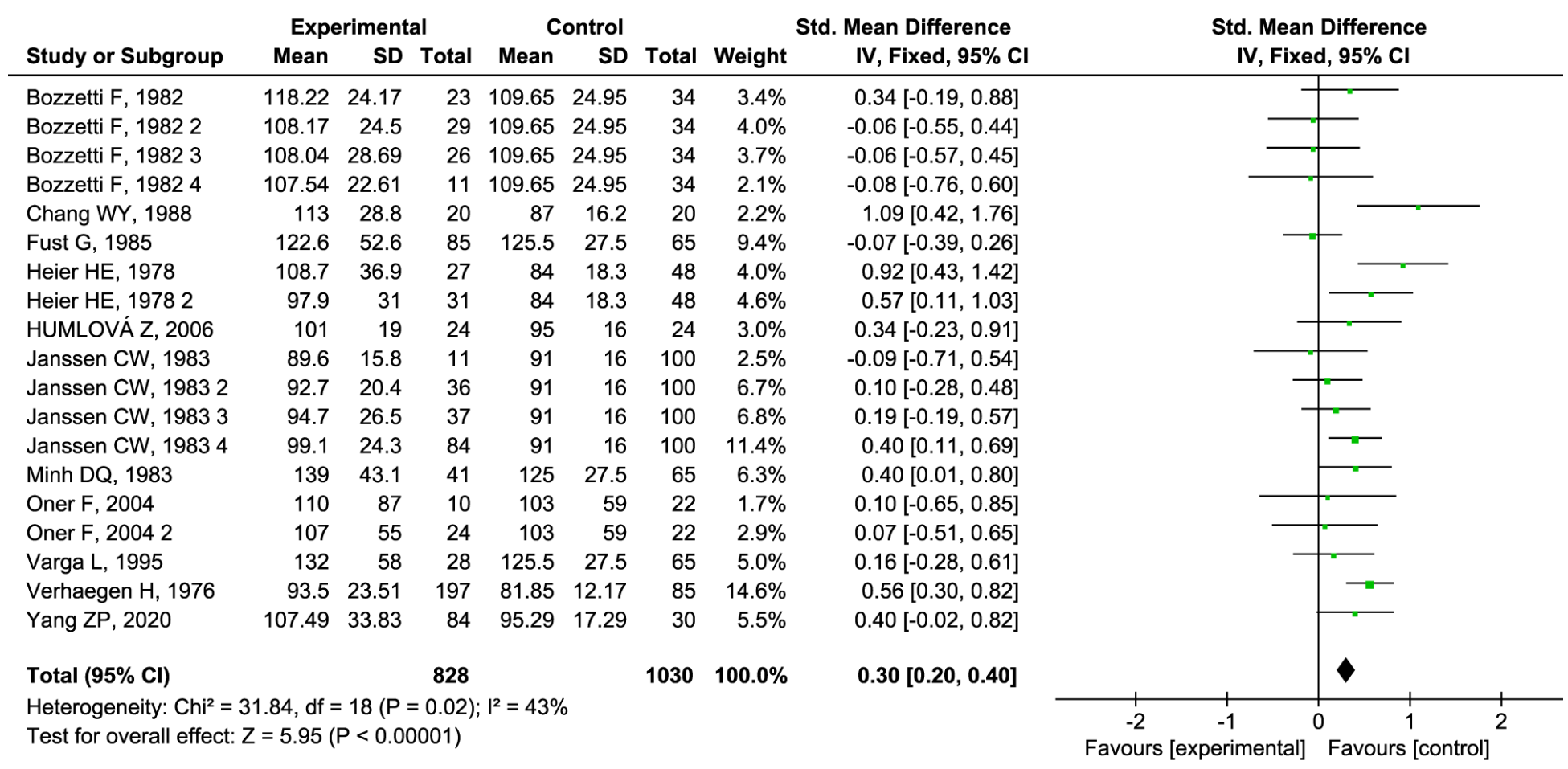

Figure 2 
Forest plot for the meta-analysis of comparing serum C3 levels in cancer patients and healthy controls. The length of the horizontal line represents the standardized mean difference and $95 \%$ confidence interval and the diamond represents the summarized effect.

\section{Begg's funnel plot with pseudo 95\% confidence limits}

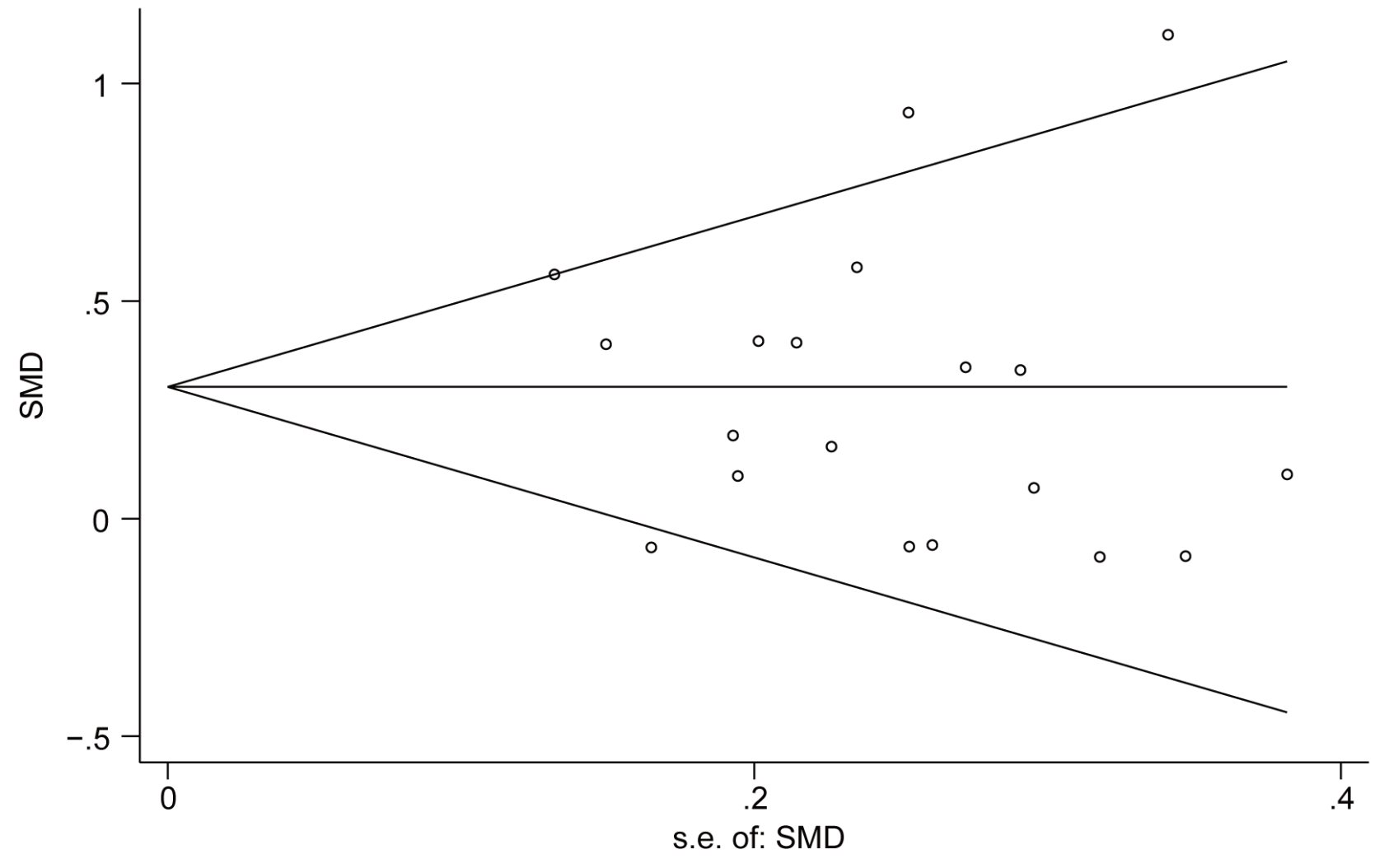

\section{Figure 3}

Funnel plot with pseudo 95\% confidence limits intervals for the examination of publication bias. SMD: standardized mean difference, SE: standard error 


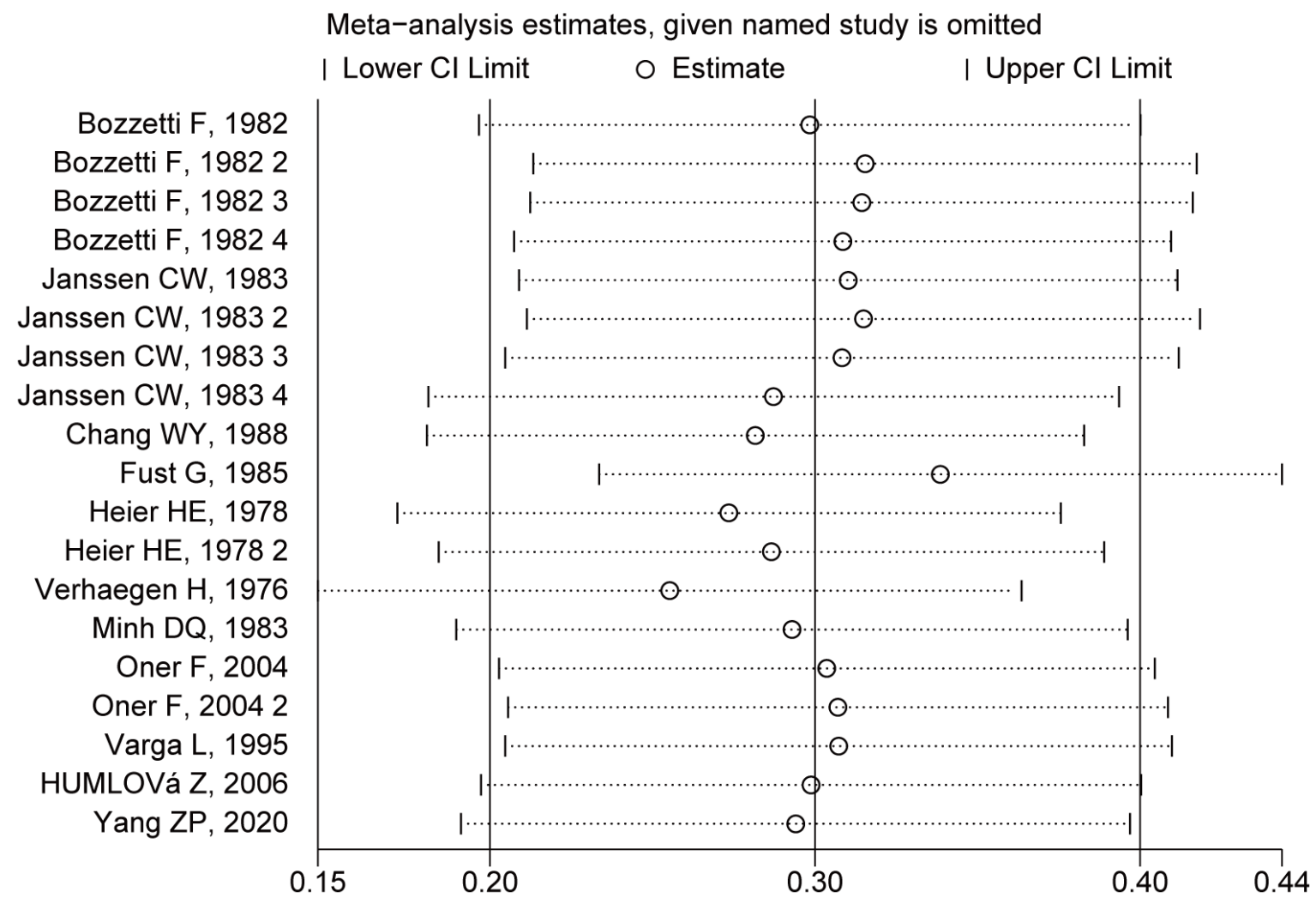

\section{Figure 4}

Sensitivity analysis of the included studies. Cl: confidence interval

\section{Supplementary Files}

This is a list of supplementary files associated with this preprint. Click to download.

- Supplementarymaterial.docx 